\title{
Structural investigation of substoichiometry and solid solution effects in $\mathrm{Ti} 2 \mathrm{Al}(\mathrm{C}-\mathrm{x}, \mathrm{N1}-\mathrm{x})(\mathrm{y})$ compounds
}

\author{
Thierry Cabioch, Per Eklund, Vincent Mauchamp and Michel Jaouen
}

\section{Linköping University Post Print}

N.B.: When citing this work, cite the original article.

Original Publication:

Thierry Cabioch, Per Eklund, Vincent Mauchamp and Michel Jaouen, Structural investigation of substoichiometry and solid solution effects in $\mathrm{Ti} 2 \mathrm{Al}(\mathrm{C}-\mathrm{x}, \mathrm{N} 1-\mathrm{x})(\mathrm{y})$ compounds, 2012, Journal of the European Ceramic Society, (32), 8, 1803-1811.

http://dx.doi.org/10.1016/j.jeurceramsoc.2011.12.011

Copyright: Elsevier http://www.elsevier.com/

Postprint available at: Linköping University Electronic Press

http://urn.kb.se/resolve?urn=urn:nbn:se:liu:diva-77516 
Structural investigation of substoichiometry and solid solution effects in $\mathrm{Ti}_{2} \mathrm{Al}\left(\mathrm{C}_{x}, \mathbf{N}_{1-x}\right)_{y}$ compounds

Thierry Cabioc' ${ }^{*}$, Per Eklund ${ }^{+}$, Vincent Mauchamp, Michel Jaouen

Département de Physique et Mécanique des Matériaux, Institut P' UPR 3346 CNRS Université de Poitiers - ENSMA, SP2MI, Téléport 2, BP30179, 86962 Futuroscope, France

\begin{abstract}
The milling, cold compaction and thermal annealing (4h-1400 ${ }^{\circ} \mathrm{C}-\mathrm{Ar}$ flow) of $\mathrm{Ti}, \mathrm{TiC}$, $\mathrm{Al}$ and $\mathrm{AlN}$ powders were used to produce $\mathrm{Ti}_{2} \mathrm{Al}\left(\mathrm{C}_{\mathrm{x}} \mathrm{N}_{(1-\mathrm{x})}\right)_{\mathrm{y}}$ compounds with $\mathrm{x}=0 ; 0.25$; $0.5 ; 0.75 ; 1$ and $0.7 \leq y \leq 1$. X-Ray diffraction analysis, Scanning Electron Microscopy observations combined with microanalysis confirmed the formation of the almost pure $\mathrm{Ti}_{2} \mathrm{AlC}_{\mathrm{x}} \mathrm{N}_{(1-\mathrm{x})}$ carbonitrides for $\mathrm{y}=1$ whereas increasing amounts of titanium aluminides were formed when $y$ decreased. Proportions of the different phases deduced from Rietveld refinements of the X-Ray diffractograms indicate that no or very poor substoichiometry in carbon was possible in carbide whereas $\mathrm{C}$ and $\mathrm{N}$ deficiency can be achieved in nitrides and carbonitrides $\mathrm{Ti}_{2} \mathrm{AlC}_{\mathrm{x}} \mathrm{N}_{(1-\mathrm{x})}$. Electron Energy Loss Spectroscopy investigations confirm that carbonitrides can have at least $20 \%$ of vacancies on the $\mathrm{C}$ or $\mathrm{N}$ site. The $a$ lattice parameter varies linearly with $\mathrm{x}$ whereas it is not the case for the $c$ lattice parameter, its values being lower for the carbonitrides. Furthermore, a strong broadening of the carbonitrides' XRD peaks is observed, a phenomenon that can be mainly attributed to $\mathrm{C}$ and $\mathrm{N}$ concentration gradients inside the samples.

*Corresponding author: E-mail address: thierry.cabioch@univ-poitiers.fr

+ Permanent address: Thin Film Physics Division, Linköping University, IFM, 58183 Linköping, Sweden
\end{abstract}




\section{Introduction}

The $\mathrm{M}_{n+1} \mathrm{AX}_{n}$ phases ( $n=1-3$, or 'MAX phases') are a group of transition metal (M) carbides and nitrides $(\mathrm{X})$ interleaved with an A-group element, with an inherently nanolaminated crystal structure that impart an exciting combination of ceramic and metallic properties to these phases. Up-to-date exhaustive reviews about these compounds can be found in Refs.[1] and [2].

It is well known that it is possible to obtain isostructural MAX phases solid solutions both on $\mathrm{M}, \mathrm{A}$, and X-sites[1]. MAX carbonitrides, e.g.. $\mathrm{M}_{n+1} \mathrm{~A}(\mathrm{C}, \mathrm{N})_{n}$ phases and in particular $\mathrm{Ti}_{2} \mathrm{Al}(\mathrm{C}, \mathrm{N})$, are the most important examples of MAX phases solid solutions on the $\mathrm{X}$ site. $\mathrm{N}$ and $\mathrm{C}$ have similar chemical bonding characteristics, resembling those of the binaries $\mathrm{TiC}$ and $\mathrm{TiN}$, and consequently one can form a wide range of $\mathrm{Ti}_{2} \mathrm{Al}(\mathrm{C}, \mathrm{N})$ solid solutions. This is important not only because it allows the understanding of the correlation between chemistry and physical properties, but also because it offers the possibility to tune the properties of these compounds. For example, $\mathrm{Ti}_{2} \mathrm{AlC}_{0.5} \mathrm{~N}_{0.5}$ has been shown[3-5] to be harder and stiffer than $\mathrm{Ti}_{2} \mathrm{AlC}$ and $\mathrm{Ti}_{2} \mathrm{AlN}$. In addition to the carbonitrides, it has recently been demonstrated that MAX oxycarbides and oxynitrides, $\mathrm{Ti}_{2} \mathrm{Al}(\mathrm{C}, \mathrm{O})$ and $\mathrm{Ti}_{2} \mathrm{Al}(\mathrm{N}, \mathrm{O})$, can be formed, either due to incorporation of oxygen from the residual gas in a vacuum deposition process[6], or due to a reaction between a $\mathrm{TiC}$, TiN, or $\mathrm{Ti}_{2} \mathrm{AlC}$ film with an $\mathrm{Al}_{2} \mathrm{O}_{3}$ substrate[7-9]. Although pure $\mathrm{M}_{2} \mathrm{AX}$ oxides, e.g. $\mathrm{Ti}_{2} \mathrm{AlO}$, are likely unstable, there are theoretical indications that the oxygen saturation content on $\mathrm{C}$ sites in $\mathrm{M}_{n+1} \mathrm{~A}(\mathrm{C}, \mathrm{O})_{n}$ solid solutions may be as large as $25-75 \%[10]$.

The general formula $\mathrm{M}_{n+1} \mathrm{AX}_{n}$ gives the different MAX stoichiometries as 211 $(\mathrm{n}=1), 312(\mathrm{n}=2)$, and $413(\mathrm{n}=3)$. However, "211", "312", and "413" are not necessarily the exact stoichiometries. It is well documented that the binary carbides and nitrides, which constitute the MX building blocks in the MAX phases, can exist in a wide composition range. $\mathrm{TiC}$, for example, has a single-phase field from $\mathrm{TiC}_{0.5}$ to $\mathrm{TiC}_{0.98}$ [11] and some of its physical properties (e.g. electrical resistivity, thermal conductivity) $[12,13]$ strongly vary with the introduction of carbon vacancies. It also exists a wide range of solid solutions between $\mathrm{TiN}$ and $\mathrm{TiC}$. Indeed, $\mathrm{Ti}(\mathrm{C}, \mathrm{N})$ layers are largely used for cutting tools and wear resistant coatings. Wear resistance improvement and hardness increase of Titanium carbonitrides thin films were extensively studied over the last 20 years. Not surprisingly, substoichiometry in $\mathrm{C}$ and $\mathrm{N}$ can be easily obtained for such carbonitrides.

Substoichiometry of the $\mathrm{X}$ component in the MAX phases is therefore expected. Several results in the literature show that $\mathrm{Ti}_{2} \mathrm{AlN}$ [14], $\mathrm{Ti}_{4} \mathrm{AlN}_{3}$ [15], $\mathrm{Ti}_{3} \mathrm{AlC}_{2}$ [16], and $\mathrm{V}_{4} \mathrm{AlC}_{3}[17]$, can be substantially substoichiometric in the $\mathrm{X}$ element. From Density Functional Theory (DFT) calculations, it has been predicted that the introduction of $\mathrm{N}$ or $\mathrm{C}$ vacancies in $\mathrm{Ti}_{4} \mathrm{AlN}_{3-\delta}$ and $\mathrm{V}_{4} \mathrm{AlC}_{3-\delta}$, respectively, increases the phase stability relative to the stoichiometric 413 phases[18,19]. In contrast, a similar calculation for $\alpha$ $\mathrm{Ta}_{4} \mathrm{AlC}_{3}$ suggested that a small amount of $\mathrm{C}$ vacancies in $\mathrm{Ta}_{4} \mathrm{AlC}_{3}$ reduces the stability compared to the stoichiometric structure[20], and there are no experimental indications that $\alpha-\mathrm{Ta}_{4} \mathrm{AlC}_{3}$ is understoichiometric in C[21-22]. Nevertheless, there is most likely a stoichiometry range for X-site vacancies for most MAX phases, as for the binary carbides and nitrides.

The combination of $\mathrm{X}$-site substoichiometry in a solid solution is interesting to study from a fundamental point-of-view and also because it is known to affect proper- 
ties such as hardness and conductivity. While Pietzka and Schuster[23] reported a continuous range of solid solutions in $\mathrm{Ti}_{2} \mathrm{Al}\left(\mathrm{C}_{x}, \mathrm{~N}_{1-x}\right)_{0.8}$, systematic studies of these effects are essentially lacking. Therefore, in this paper we report on the possibility of having $\mathrm{C}$ and/or $\mathrm{N}$ vacancies in the $\mathrm{Ti}_{2} \mathrm{Al}(\mathrm{C}, \mathrm{N})$ compounds by varying systematically the carbon and nitrogen concentrations in reactants and then by considering the products obtained after performing an identical thermal treatment.

\section{Experimental Details}

$\mathrm{Ti}_{2} \mathrm{Al}\left(\mathrm{C}_{x}, \mathrm{~N}_{1-x}\right) \mathrm{y}$ compounds were synthesized by using conventional powder metallurgy techniques. Commercial $\mathrm{Ti}, \mathrm{Al}, \mathrm{AlN}$ and $\mathrm{TiC}$ powders were carefully weighed to obtain the nominal compositions: $2 \mathrm{Ti}: 1.1 \mathrm{Al}: x y \mathrm{C}:(1-x) y \mathrm{~N}$. An excess of $10 \% \mathrm{Al}$ was chosen to compensate the loss of aluminium by evaporation during the sintering process. After 4 hours of mixing (Turbula ${ }^{\mathrm{TM}}$ shaker), cylindrical compacts, 12 $\mathrm{mm}$ in diameter and 3 or $4 \mathrm{~g}$ in weight, of the mixed powders were hand pressed (uniaxial cold compaction). The so obtained cylinders present a good green strength and an open porosity of $\sim 40 \%$. Natural reactive sintering of all samples was performed in a furnace (Nabertherm ${ }^{\mathrm{TM}}$ ) maintaining a primary vacuum up to $400^{\circ} \mathrm{C}$ to avoid oxygen contamination. A constant argon flow was then applied for higher temperatures till the end of the thermal procedure which consisted in maintaining the samples at $1400^{\circ} \mathrm{C}$ for 4 hours. The porosity and the true density of the so obtained samples were measured by using Archimedes' law and Helium picnometry. One face of the cylindrical samples was mechanically polished prior to further characterizations. X-ray diffraction (XRD) data were obtained on the polished face using the $\mathrm{Cu}$ K $\alpha$ radiation of a Bruker D8 advance diffractometer in Bragg-Brentano geometry, the divergence and receiving slits being set at $0.02 \mathrm{~mm}$. The selected $2 \theta$ range $\left(10-80^{\circ}\right)$ covers most of the intense peaks of $\mathrm{Ti}_{2} \mathrm{AlC}_{\mathrm{x}} \mathrm{N}_{1-\mathrm{x}}$. The instrument was operating at $40 \mathrm{kV}$ and $40 \mathrm{~mA}$. Steps interval of $0.02^{\circ}$ or $0.03^{\circ}(2 \theta)$ and counting time varying between 5 and $20 \mathrm{~s}$ for each step were used. The pattern of a $\mathrm{Cr}_{2} \mathrm{O}_{3}$ powder (Standard NIST 600) was collected at the same geometrical conditions to generate an instrumental resolution function to account for the experimental broadening. Rietveld refinements of the diffractograms were performed using the Materials Analysis Using Diffraction (MAUD) software[24].

The polished surfaces of all the samples were also examined in a scanning electron microscope (SEM) (JEOL 5600 LV). Energy Dispersive X-Ray microanalysis (EDX) were performed in the SEM to determine the global Ti/Al ratio of the sample ; but also that of the different phases observed, at a micrometric scale, on backscattered electrons SEM images. Some samples were prepared for Transmission Electron Microscopy (TEM). The polished surfaces of sintered samples were scratched by a diamond tool to get small amount of powders. These last were hand milled with an agate mortar in an agate crucible to obtain, on the boarder of micrometric grains, areas thin enough for TEM and Electron Energy Loss Spectroscopy (EELS) analysis. TEM-EELS experiments were performed in a JEOL 2200-FS operating at $200 \mathrm{kV}$ and equipped with an in-column omega filter. Spectra were dark count corrected and deconvoluted from multiple scattering using a Fourier-Ration technique. The standard procedure implemented in the Gatan Digital Micrograph software was used to perform the quantification of $\mathrm{C} / \mathrm{N}$ ratio from the carbon and nitrogen $K$ edges. The error on a single quantification is estimated to be on the order of $10 \%$ what was confirmed when performing measurements on various grains of the same composition. 


\section{Results and Discussion}

\section{1. $\operatorname{Ti}_{2} \mathrm{AlC}_{\mathrm{x}} \mathbf{N}_{(1-\mathrm{x})}$ carbonitrides}

Results obtained on $\mathrm{Ti}_{2} \mathrm{AlC}_{\mathrm{x}} \mathrm{N}_{(1-\mathrm{x})}$ compounds (then after called "stoichiometric compounds" for simplicity to distinguish them from nitrogen- and/or carbon-deficient compounds) are here first described before discussing the results obtained for nitrogenand/or carbon-deficient compounds. Porosimetry experiments showed that all samples were porous whatever the stoichiometry is. If the carbide sample $(x=1)$ exhibits the largest porosity (45\%), this last progressively decreases with an increasing nitrogen content down to a value of $32 \%$ for the pure nitride $(x=0)$. SEM observations confirm these results, as numerous pores are observed (Figure 1). On Figure $1 \mathrm{~b}$ are evidenced grains, $2-10 \mu \mathrm{m}$ in size, as well as flat polished sections of dense aggregates. For all samples, EDX showed that the overall Ti/Al ratio is very close to 2 . This confirms the expected loss of approximately $10 \%$ of the aluminum during the reactive sintering of the samples. No oxygen was detected whereas $K_{\alpha}$ lines from $\mathrm{C}$ and $\mathrm{N}$ were easily observed, especially on the micrometric grains as those seen in Figure 1b. In contrast, at the center of some of the flat denser polished section, only $\mathrm{Ti}$ and $\mathrm{Al}$ were detected showing the presence of small amounts of titanium aluminides ( $\mathrm{TiAl}$ and/or $\mathrm{TiAl}_{2}$ ) in the samples. $\mathrm{Ti}_{2} \mathrm{AlC}_{\mathrm{x}} \mathrm{N}_{(1-\mathrm{x})}$ compounds were characterized by XRD and Figure $2 \mathrm{a}$ is a typical example of the diffractograms obtained in the $10-80^{\circ} 2 \theta$ range. From these XRD spectra, it appears that the samples are not single phased. In addition to the predominant presence of diffraction peaks from the MAX phase $\mathrm{Ti}_{2} \mathrm{AlC}_{\mathrm{x}} \mathrm{N}_{(1-\mathrm{x})}$, diffraction peaks attributed to titanium aluminides $\left(\mathrm{TiAl}\right.$ or $\left.\mathrm{TiAl}_{2}\right)$, titanium carbonitrides $\left(\mathrm{TiC}_{\mathrm{x}} \mathrm{N}_{(1-\mathrm{x})}\right)$ and $\mathrm{Ti}_{3} \mathrm{AlC}_{2}$ were observed. Good Rietveld refinements of the XRD data $\left(\mathrm{R}_{\mathrm{w}}\right.$ generally below $10 \%$ ) allow to quantify the amounts of these secondary phases (this will be more precisely described in the next section). As a general trend, all samples contain very small quantities of titanium aluminides ( 0 to 4 weight $\%$ ) and titanium carbonitrides ( 0 to 2 weight $\%$ ), and increasing amounts of $\mathrm{Ti}_{3} \mathrm{AlC}_{2}$ were obtained for carbon-rich compounds ( 7.5 and 21.4 weight $\%$ for $x=0.75$ and $x=1$, respectively). On the basis of these observations, it is possible to conclude that the large amount of micrograins observed by SEM are $\mathrm{Ti}_{2} \mathrm{AlC}_{\mathrm{x}} \mathrm{N}_{(1-\mathrm{x})}$ grains. It is important to note that no preferential orientation of these micrograins was evidenced from SEM observations. This is in accordance with the fact that no texture has to be introduced to refine the X-ray diffractograms, and is of importance to the reliability of the amount of the different phases computed from Rietveld refinement. These remarks remain true for all the samples and XRD data discussed in this work.

Figure $2 b$ shows $X$-Ray diffractograms for different $x$ values in a smaller $2 \theta$ range. Two main features are observed: a progressive shift of the diffraction peaks from $\mathrm{Ti}_{2} \mathrm{AlC}_{\mathrm{x}} \mathrm{N}_{(1-\mathrm{x})}$ towards lower $2 \theta$ values when the amount of carbon increases, and a strong broadening of the diffraction peaks for the carbonitrides in comparison to the pure $\mathrm{Ti}_{2} \mathrm{AlN}$ and $\mathrm{Ti}_{2} \mathrm{AlC}$.

The first feature is explained by an evolution of the $a$ and/or $c$ lattice parameters of the hexagonal MAX phase. This evolution of the lattice parameters is plotted in Figure 3. The obtained values are given in Table 1 and compared to literature values. From Rietveld refinements of the XRD data, quite accurate values of the $a$ and $c$ lattice parameters were obtained using the MAUD software. Uncertainties of $5 \times 10^{-5} \AA$ and $5 \times 10^{-}$ 
${ }^{4} \AA$ were typically obtained for $a$ and $c$ parameters, respectively. We can immediately note that the $a$ lattice parameter is a linear function of $\mathrm{x}$. Such a linear relation was also observed for the titanium carbonitrides $\mathrm{TiC}_{\mathrm{x}} \mathrm{N}_{(1-\mathrm{x})}$. A comparison of the evolution of the interatomic distance between $\mathrm{Ti}$ atoms in the case of $\operatorname{TiC}_{\mathrm{x}} \mathrm{N}_{(1-\mathrm{x})}[25]$ and $\operatorname{Ti}_{2} \mathrm{Al}\left(\mathrm{C}_{\mathrm{x}} \mathrm{N}_{(1-\mathrm{x})}\right)$ is also given in Figure 3(a). These similarities are expected given the close relationships between the $M_{n+1} X_{n}$ layers of the MAX phase and that of the corresponding binary MX compounds. Even if inhomogeneities in the carbon and nitrogen atomic distribution cannot be excluded, these results evidenced the existence of a random solid solution on the $\mathrm{X}$ site. Such a conclusion is in accordance with that of Arroyave et al [32]. On the basis of ab initio investigations, these authors concluded that a short range ordering between $\mathrm{C}$ and $\mathrm{N}$ atoms is energetically favored, but the $\mathrm{C}-\mathrm{N}$ interaction is so low that one can easily obtain a random solid solution. The values of the a parameter obtained here are in very good agreement with experimental ones from the literature, especially for $\mathrm{x}=0,0.5$. For $\mathrm{x}=1$, the agreement is good too, but it is worth mentioning that high discrepancies exist for literature values.

In contrast to the case of the a parameter, a quite surprising result is obtained for the evolution of the $c$ parameter since its value is always lower for carbonitrides than for the pure carbide or pure nitride (but very close to the latter). Such an observation was already reported for $\mathrm{x}=0.5$ by other authors $[3,4]$ and a very similar evolution is obtained for calculated values [32]. This work thus confirms that, at least up to $75 \%$ of carbon, carbonitrides have lower $c$ values compared to the pure ternary compounds. Further theoretical investigations are required to explain this behavior. Nevertheless, such a decrease in the $c$ parameter may reflect a breaking of symmetry of the charge modulation along the $\mathrm{c}$ axis compared to the one occurring in the defined ternary compounds. Furthermore one will have to explore the range $0.75 \leq \mathrm{x} \leq 1$ to determine if this observed decrease of the $c$ value is a general trend for the titanium aluminides carbonitrides. On the other hand, one should pay attention on the fact that in the literature, a value of $\mathrm{c}=1.36 \mathrm{~nm}$ is generally given for $\mathrm{Ti}_{2} \mathrm{AlC}$ [31]. By considering this value, one could consider that the value of the $\mathrm{c}$ parameter remains almost constant irrespective of $\mathrm{x}$ in $\mathrm{Ti}_{2} \mathrm{AlC}_{\mathrm{X}} \mathrm{N}_{(1-\mathrm{x})}$. Furthermore, as already mentioned, strong discrepancies exist in the literature for the value of the $\mathrm{c}$ parameter (see figure $3 \mathrm{~b}$ and table 1 ). This is poorly discussed in the literature. Only Pietzka et al [29] noticed the phenomenon and concluded that this can be attributed to the fact that $\mathrm{Ti}_{2} \mathrm{AlC}$ can have a strong carbon deficiency (this will be more discussed in the next section).

The second important feature, the diffraction peak broadening for the carbonitrides (more pronounced for $\mathrm{x}=0.5$ ), most likely originates from microstrains. Broadening due to a decreasing size of the coherent diffraction domains can be safely excluded since this broadening effect does not occur for some diffraction peaks (especially for $0002 n, n=1,2,3, \ldots)$. The fact that the broadening of the diffraction peak varies with the plane index clearly indicates it results from anisotropic microstrains. This is confirmed by the very good quality of Rietveld refinements obtained when considering Popa rules[33]for refining the shape of the peaks. As described by Popa, there are relationships between the crystallography of the studied phase and the broadening of the diffraction peaks of different index. In the present case (hexagonal symmetry) three independent microstrain coefficients can be computed to achieve good refinements of all diffraction peaks. Values of the microstrain can thus be determined for all planes; on Figure 4 are reported these values for the most intense Bragg's reflections. Larger values are obtained for planes perpendicular to the $c$ axis of the hexagonal unit cell. In contrast, 
almost no microstrain exists along the basal planes (i.e. (0002n) planes). This variation in microstrain broadening of the diffraction peaks can be explained by considering carbon and nitrogen concentration gradients. Indeed, small variations in nitrogen and carbon content in the carbonitride lead to different $a$ and $c$ parameter values. In contrast to what happens when using Hot Isostatic Pressure (HIP) methods, slow diffusion processes act during the reactive sintering of the samples and thus larger concentration inhomogeneities on the $\mathrm{X}$ site can be obtained for natural sintering. Furthermore, whereas an increase of $10 \%$ of carbon in the carbonitride leads to an increase of $0.25 \%$ of the $a$ lattice parameter, the related $c$ value is only modified by about $0.02 \%$. In other words, whereas $a$ strongly varies, $c$ remains almost constant for $0 \leq \mathrm{x} \leq 0.75$. This fully explains why no noticeable broadening of the $(0002 \mathrm{n})$ diffraction peaks is observed. In contrast, this will give rise to broad diffraction peaks for nonbasal planes. Finally, it is important to note that this explanation, i.e. the assumption of existing $\mathrm{N}$ and $\mathrm{C}$ concentration gradients, does not exclude that intrinsic microstrains can exist in MAX phase carbonitrides, but their levels will likely be much lower than those here obtained.

\section{2. $\mathbf{N}$ and $\mathrm{C}$ deficiency in $\operatorname{Ti}_{2} \mathrm{Al}\left(\mathrm{C}_{\mathrm{x}} \mathbf{N}_{(1-\mathrm{x})}\right)_{\mathrm{y}}$ carbonitrides}

In the previous section, we assumed that $y=1$. One of the main goal of this work is to study the possibility to achieve substoichiometry in carbon and/or nitrogen in $\mathrm{Ti}_{2} \mathrm{Al}(\mathrm{C}, \mathrm{N})$ compounds and initial amount of the powders were chosen to try to obtain $\mathrm{y}$ values varying from 0.7 to 1 . For the ideal case, the synthesis of single-phased MAX phase material implies that the desired y value is obtained. If not the case, i.e. a multiphased material is obtained and the proportion of $\mathrm{Ti}_{2} \mathrm{Al}(\mathrm{C}, \mathrm{N})$ is $\mathrm{y}$, it means that no carbon and/or nitrogen substoichiometry is achieved in the MAX phase. For intermediate cases, the true values of $x$ (noted $x_{t}$ ) and $y$ (noted $y_{t}$ ) in the material have to be determined. In the following, $x$ and $y$ designate the stoichiometry of the reactants whereas $x_{t}$ and $\mathrm{y}_{\mathrm{t}}$ as the true values for the product $\mathrm{Ti}_{2} \mathrm{Al}\left(\mathrm{C}_{\mathrm{x}_{\mathrm{t}}} \mathrm{N}\left(1-\mathrm{x}_{\mathrm{t}}\right)\right)_{\mathrm{y}_{\mathrm{t}}}$.

On Figure 5 are plotted the typical X-Ray diffractograms related to decreasing $y$ values. Whatever the value of $x$ is, one observes a contribution of titanium aluminides ( TiAl and $\mathrm{Ti}_{3} \mathrm{Al}$ ) to the XRD spectra that increases with decreasing y values. This increasing amount of these two titanium aluminides is confirmed by SEM and EDX (not shown). Larger dense areas, free of $\mathrm{N}$ and $\mathrm{C}$ as determined by EDX, can be observed in a backscattering mode whereas the micrograins at the border of these areas and between these last are grains of MAX phase. No noticeable modification of the MAX phase grain size was deduced from SEM observations. From porosimetry experiments, we also note that the samples' density increases when y values decrease. This can simply be explained by the increasing amount of dense intermetallic materials for decreasing values of $y$.

These observations prove that single-phased material is not obtained in every case and that true values of carbon and nitrogen concentration in the MAX phase has to be determined. Unfortunately, quantification of $\mathrm{C}$ and $\mathrm{N}$ inside one phase of a multiphased porous material is not obvious since most commonly used techniques determine global $\mathrm{C}$ and $\mathrm{N}$ concentrations. Therefore we used EELS as a tool to determine $\mathrm{C}$ and $\mathrm{N}$ concentrations in selected samples to assess the accuracy of the $\mathrm{x}_{\mathrm{t}}$ and $\mathrm{y}_{\mathrm{t}}$ values deduced from the phases' quantification obtained from Rietveld refinement of X-ray diffractograms. 
All X-Ray diffractograms were refined to determine the amount of the different phases in our samples. Figure 6 gives a summary of the proportion in weight of the different phases present in our samples deduced from these refinements that were all of good quality $\left(\mathrm{R}_{\mathrm{w}}\right.$ values below $\left.10 \%\right)$. As already mentioned, an increasing amount of titanium aluminides ( $\left.\mathrm{TiAl}, \mathrm{Ti}_{3} \mathrm{Al}\right)$ is observed when $\mathrm{y}<1$. Using fractions of the different phases deduced from these refinements, we computed the true density of the related samples. The values obtained were very close to those obtained by porosimetry (difference below 1\%). Note that helium picnometry directly gives the true density since we have only open porosity in our samples.

The values of $x_{t}$ and $y_{t}$ were then deduced from the following balance equation:

$2 \mathrm{Ti}+\mathrm{Al}+x y \mathrm{C}+(1-x) y \mathrm{~N} \rightarrow \alpha_{1} \mathrm{Ti}_{2} \mathrm{AlC}_{s} \mathrm{~N}_{t}+\alpha_{2} \mathrm{Ti}_{3} \mathrm{AlC}_{2}+\alpha_{3} \mathrm{TiC}_{v} \mathrm{~N}_{w}+\alpha_{4} \mathrm{TiAl}+\alpha_{5}$ $\mathrm{Ti}_{3} \mathrm{Al}+\alpha_{6} \mathrm{TiAl}_{2}+\alpha_{7} \mathrm{Ti}_{3} \mathrm{AlN}(1)$

where $\alpha_{i}$ denotes the molar content of the different products for one mole of reactant $\mathrm{Ti}_{2} \mathrm{Al}\left(\mathrm{C}_{x} \mathrm{~N}_{(1-x)}\right)_{y}$. Their values are deduced from weight fractions from the different phases. If we consider the balance for every atomic species, we get:

For Ti : $2=2 \alpha_{1}+3 \alpha_{2}+\alpha_{3}+\alpha_{4}+3 \alpha_{5}+\alpha_{6}+3 \alpha_{7}$

For $\mathrm{Al}: 1=\alpha_{1}+\alpha_{2}+\alpha_{4}+\alpha_{5}+2 \alpha_{6}+\alpha_{7}$

For C: $x y=s \alpha_{1}+2 \alpha_{2}+v \alpha_{3}$

For $\mathrm{N}:(1-x) y=t \alpha_{1}+w \alpha_{3}+\alpha_{7}$

In these relations, $s, t, v$ and $w$ are then the four unknown parameters one wants to compute. At first, a very simple assumption can be made for $v$ and $w(\mathrm{C}$ and $\mathrm{N}$ content of the titanium carbonitride) in that $\mathrm{v} \approx \mathrm{x}$ and $\mathrm{w} \approx(1-\mathrm{x})$. Such an assumption is reasonable because a full solid solution can easily be obtained for titanium carbonitrides and we can consider that $\mathrm{C}$ and $\mathrm{N}$ concentrations in the formed $\operatorname{Ti}(\mathrm{C}, \mathrm{N})$ are very similar to those of the reactants. Secondly, and it is the most important consideration, values of $\alpha_{3}$ $(\mathrm{Ti}(\mathrm{C}, \mathrm{N})$ proportion in the products) are very small (the maximum value is $2 \%$ and $\mathrm{Ti}(\mathrm{C}, \mathrm{N})$ presence is noted for only 4 out of 16 studied samples). With such assumptions, $s$ and $t$ can be obtained from:

$s=\left[x y\left(1-\alpha_{3}\right)-2 a_{2}\right] / \alpha_{1}=x_{t} y_{t}$

$t=\left[(1-x) y\left(1-\alpha_{3}\right)-\alpha_{7}\right] / \alpha_{1}=\left(1-x_{t}\right) y_{t}$

this leads to:

$y_{t}=s+t=\left[y\left(1-\alpha_{3}\right)-2 a_{2}-\alpha_{7}\right] / \alpha_{1}$

$\mathrm{x}_{\mathrm{t}}=\left[x y\left(1-\alpha_{3}\right)-2 a_{2}\right] /\left[y\left(1-\alpha_{3}\right)-2 a_{2}-\alpha_{7}\right]$

From this set of equations, $x_{t}$ and $y_{t}$ values can thus be easily computed. Nevertheless, this model suffers from uncertainties which have to be considered before analyzing the values of $x_{t}$ and $y_{t}$. The MAUD software we use to perform Rietveld refinement gives uncertainties values for the $\alpha_{i}$ parameters. These uncertainties strongly vary with the amount of the different phases. Typically, whereas an uncertainty $\Delta \alpha_{1}=0.01$ to 0.02 was obtained for the amount of the main phase $\left(\mathrm{Ti}_{2} \mathrm{Al}(\mathrm{C}, \mathrm{N})\right)$, relative uncertainties $\Delta \alpha_{i} / \alpha_{i}$ varying between 5 to $30 \%$ were obtained for the secondary phases, the highest relative uncertainties being obtained for very low values of $\alpha_{\mathrm{i}}(\leq 1 \%)$. Uncertainties given below for $x_{t}$ and $y_{t}$ were computed from uncertainties values given by the software multiplied by a factor 2 to exclude any minimization of the errors. Furthermore, it is important to note that equations (2) and (3) (balance of Ti and $\mathrm{Al}$ ) were well verified by using $\alpha_{i}$ parameters obtained from the Rietveld refinement of the XRD data. This constitutes more evidence for considering the values of the $\alpha_{i}$ parameters used in this work as quite accurate. 
Table 2 gives the values of $x_{t}$ and $y_{t}$ deduced form (6) and (7) as well as the corresponding uncertainties. Unsurprisingly, the $x_{t}$ values (true concentration in $C$ of the product) are very close to that of the reactants $x$. More interesting are the values of nitrogen and/or carbon deficiency that can be obtained. In every case, $\mathrm{y}_{\mathrm{t}}>\mathrm{y}$ (with the noticeable exception $\mathrm{x}=1 ; \mathrm{y}=1)$. In other words, single-phased samples are not obtained and the natural reactive sintering process here used does not allow to get a $\operatorname{Ti}_{2} \mathrm{Al}(\mathrm{C}, \mathrm{N})$ material having a large amount of vacancies on the $\mathrm{N}$ and $\mathrm{C}$ sites. Another conclusion that can be addressed from Table 2 is that carbonitrides are able to possess $\mathrm{N}$ and $\mathrm{C}$ deficiency, the lowest values of $y_{t}$ being obtained for $x_{t}=0.5$. For $\operatorname{Ti}_{2} \operatorname{AlN}_{y_{t}}$ (i.e., $x=0$ ), nitrogen deficiency can also be obtained but for higher values of $\mathrm{y}_{\mathrm{t}}$. Finally, the case of pure carbides can be considered as quite different. Indeed, whereas no carbon deficiency is obtained for $y<1$, a lower value of $y_{t}$ is obtained for $y=1$. This is a quite surprising result since, in that specific case, $\mathrm{C}$ deficiency was not supposed to occur. One can suspect the $\alpha_{i}$ parameters obtained from Rietveld refinement to be questionable in that case. Another carbide $\mathrm{Ti}_{2} \mathrm{AlC}$ sample $(\mathrm{y}=1)$ was synthesized and very similar amounts of the different phases were computed. Furthermore the fact that $\mathrm{Ti}_{2} \mathrm{AlC}$ and $\mathrm{Ti}_{3} \mathrm{AlC}_{2}$ are the only carbide phases identified on the X-Ray spectra reveals that carbon deficiency in $\mathrm{Ti}_{2} \mathrm{AlC}$ and/or in $\mathrm{Ti}_{3} \mathrm{AlC}_{2}$ compounds has to be considered to fully explain the carbon balance. For $\mathrm{y}<1$, no or almost no carbon understoichiometry is obtained for $\mathrm{Ti}_{2} \mathrm{AlC}$ and this allows to propose that $\mathrm{Ti}_{3} \mathrm{AlC}_{2}$ can be carbon deficient whereas it is not the case for $\mathrm{Ti}_{2} \mathrm{AlC}$. For $\mathrm{x}=\mathrm{y}=1$, assuming that carbon deficiency can only occur for $\mathrm{Ti}_{3} \mathrm{AlC}_{(2-\mathrm{x})}$, new balance equations give a stoichiometry $\mathrm{Ti}_{3} \mathrm{AlC}_{1.5}$ for the $312 \mathrm{MAX}$ phase. This conclusion (i.e., almost no carbon deficiency can be achieved in $\mathrm{Ti}_{2} \mathrm{AlC}$ compound) is in contradiction with that of Pietzka et al [23] who concluded that a value of $\mathrm{y}_{\mathrm{t}}=0.7$ is generally obtained in their samples for $\mathrm{Ti}_{2} \mathrm{AlC}_{\mathrm{y}_{\mathrm{t}}}$. It is quite difficult to understand this difference since our study unambiguously shows that, after $4 \mathrm{~h}$ at $1400^{\circ} \mathrm{C}$, we do not obtain carbon understoichiometry in this compound, even when the reactants where chosen so that $\mathrm{y}=0.7$. In their work, Pietzka et al used the same reactants (i.e. $\mathrm{Ti}$, $\mathrm{Al}$ and $\mathrm{C}$ powders) but with longer annealing time $\left(20 \mathrm{~h}\right.$ at $1375^{\circ} \mathrm{C}$ or $15 \mathrm{~h}$ at $1485^{\circ} \mathrm{C}$ in [23] or $20 \mathrm{~h}$ at $1300^{\circ} \mathrm{C}$ in [29]). It is possible that thermodynamic equilibrium was reached in Pietzka's studies whereas it is not the case in the present study ( $4 \mathrm{~h}$ at $1400^{\circ} \mathrm{C}$ in an open system). The $\mathrm{C}$ and $\mathrm{N}$ carbon concentration gradient outlined in the previous section can also be explained by the short annealing time. The products obtained in this study should then be considered as representatives of those generally obtained after a conventional heat treatment rather than those obtained at thermodynamic equilibrium at $1400^{\circ} \mathrm{C}$.

To assess the main conclusions of this work addressed on the basis of Rietveld refinement of $\mathrm{X}$-Ray diffractograms, two samples $(\mathrm{x}=0.5$ and $\mathrm{y}=1 ; \mathrm{x}=0.5$ and $\mathrm{y}=0.8)$ were examined in a TEM. The $\mathrm{C}$ and $\mathrm{N}$ contents of these two samples were also deduced from EELS investigations for comparison. The nanolamellar structure of the MAX phase was easily evidenced in high resolution images of some grains (not shown) and EELS spectra were recorded on areas presenting electron diffraction patterns characteristic of the MAX phase. The $\mathrm{C}$ and $\mathrm{N}$ content of the two MAX phase carbonitrides obtained from EELS are given in table 3. Like it was found from Rietveld analysis of the XRD data, values of $x_{t}$ are very close to that of $x$. The excellent agreement between values deduced from EELS experiments and Rietveld refinement of XRD confirms that $\mathrm{C}$ and $\mathrm{N}$ deficiency can be obtained for $\mathrm{Ti}_{2} \mathrm{AlC}_{\mathrm{x}} \mathrm{N}_{(1-\mathrm{x})}$ compounds. Finally, it is important to mention that no O-K edge was observed on the EELS spectra, i.e. the two 
probed samples do not contain any noticeable amount of oxygen $(\mathrm{O}-\mathrm{K}$ edge is observable even for small amounts of oxygen). This is an important result since it rules out the possibility of oxygen incorporation on the $\mathrm{X}$ for $\mathrm{N}$ and $\mathrm{C}$ deficient carbonitride samples as is the case for $\mathrm{Ti}_{2} \mathrm{Al}(\mathrm{C}, \mathrm{O})$ compounds.

On the basis of XRD results, it is also possible to extract the evolution of the $a$ and $c$ lattice parameters for the various values of $\mathrm{x}_{\mathrm{t}}$ and $\mathrm{y}_{\mathrm{t}}$ of the $\mathrm{Ti}_{2} \mathrm{Al}\left(\mathrm{C}_{\mathrm{x}} \mathrm{N}_{(1-\mathrm{x})}\right)_{\mathrm{y}}$ compounds. The evolution of the lattice parameters is plotted in Figure 6. Whereas a very slight decrease of the $a$ parameter is observed when $\mathrm{y}_{\mathrm{t}}$ decreases, it is the reverse concerning the $c$ parameter. For pure carbides $(\mathrm{x}=1)$, the values of $a$ and $c$ parameters are not reported for $y=1$ since the $y_{t}$ value is questionable in that case. Again, for same values of $\mathrm{y}_{\mathrm{t}}, c$ values for the carbonitrides are lower than pure nitride and carbide ones. On the opposite, $a$ values seem to obey to a Vegard's law irrespective of $y_{t}$, as it is the case for unit cell volumes. We can also note that the unit cell volumes remain almost constant whatever $\mathrm{y}_{\mathrm{t}}$ is for a given $\mathrm{x}_{\mathrm{t}}$ (figure $7 \mathrm{c}$ ). Very similar values can be deduced from literature with the exception of the values of Pietzka et al [23] that are slightly different.

One note only very slight modifications of the unit cell parameters when $\mathrm{C}$ and $\mathrm{N}$ deficiencies are taken into account. Nevertheless, this last figure clearly shows, with the exception of the pure carbide $\mathrm{Ti}_{2} \mathrm{AlC}$, that small discrepancies will be found for unit cell parameters of some MAX phases if assuming exact 211, 312 or 413 stoichiometries are considered as it is generally the case in the literature dedicated to the determination of the unit cell parameters of MAX phases, either from ab-intio calculations or from experiments. Again, the carbide case has to be outlined. On the basis of the obtained values of the carbon stoichiometry for this compound, the present study indicates that $\mathrm{Ti}_{2} \mathrm{AlC}$ can be considered as a definite compound with a carbon content close to one. On the other hand, the a and c lattice parameters slightly vary (see figure $7 \mathrm{~b}$ and $7 \mathrm{c}$ for $\mathrm{x}=1$ ) and, as already noticed in the previous section, strong discrepancies exist in the literature as far as these lattice parameters are concerned. Such observations will tend to prove that, on the contrary, $\mathrm{Ti}_{2} \mathrm{AlC}$ is not a definite compound as already mentioned by Pietzka et al [23]. Such contradictions ask of course for more detailed studies. One can propose that other considerations should be taken into account to better explain these discrepancies. For instance, some studies show that many stacking faults can exist in $\mathrm{Ti}_{2} \mathrm{AlC}$ [34]. In such a case, values of the lattice parameters conventionally deduced from X-Ray diffractograms can be strongly different from that of a fault-free phase. Finally, it must be outlined that in the present study, the lattice parameters of the compounds with nitrogen and carbon deficiencies remain almost constant irrespective of $y_{t}$, whereas it is not the case for $\mathrm{Ti}_{2} \mathrm{AlC}$ which has no or little carbon deficiency. Such an observation being the inverse from what is generally observed for line and define compounds, it appears that more detailed theoretical and experimental works are needed to better understand this phenomenon in $\operatorname{Ti}_{2} \mathrm{Al}\left(\mathrm{C}_{\mathrm{x}} \mathrm{N}_{(1-\mathrm{x})}\right)_{\mathrm{y}}$.

\section{Conclusions}

$\operatorname{Ti}_{2} \operatorname{Al}\left(\mathrm{C}_{\mathrm{X}} \mathrm{N}_{(1-\mathrm{x})}\right)_{\mathrm{y}} \mathrm{MAX}$ phases carbonitrides were synthesized by reactive natural sintering for $4 \mathrm{~h}$ at $1400^{\circ} \mathrm{C}$. As a main result, carbon- and/or nitrogen-deficiency can be achieved for the carbonitrides and nitrides but not for the carbides. The highest degree of carbon and nitrogen substoichiometry can be obtained for the carbonitrides, especially for $y=0.5$. Irrespective of the amount of the carbon and nitrogen vacancies, the $a$ 
unit cell parameter obeys a Vegard's law whereas the $c$ lattice parameter of the carbonitrides is smaller than that of the end members. At this moment, it is not possible to fully explain why it is possible to achieve to obtain higher degree of substoichiometry (i.e. lower value of y) in solid solutions than in the pure carbide and nitride and why the $c$ unit cell parameter value of the carbonitrides is lowered. There is therefore a need for theoretical studies on these specific points.

Only slight evolutions of the $a$ and $c$ lattice parameters are observed by varying $\mathrm{y}$. Nevertheless, this can explain the small discrepancies observed about the unit cell parameters values reported in the literature for MAX phases, especially for those which are not define compounds. Indeed, this study shows that quite important deviations from the "ideal" stoichiometry of the MAX Phases can be achieved. Precise values of the stoichiometry of the MAX Phase compounds need thus to be considered when the structure (e.g. unit cell parameters) or the properties are described.

\section{Acknowledgements}

The University of Poitiers is acknowledged for funding a Visiting Professor position for P. E.

\section{References}

[1] Eklund P, Beckers M, Jansson U, Högberg H, Hultman H. The $\mathrm{M}_{n+1} \mathrm{AX}$. phases: Materials science and thin-film processing. Thin Solid Films 2010;518:1851-1878.

[2] Wang JY, Zhou YC. Recent progress in theoretical prediction, preparation, and characterization of layered ternary transition-metal carbides. Annu Rev Mater Res 2009;39:10.1-10.29.

[3] Barsoum MW, Ali M, El-Raghy T. Processing and characterization of $\mathrm{Ti}_{2} \mathrm{AlC}$, $\mathrm{Ti}_{2} \mathrm{AlN}$ and $\mathrm{Ti}_{2} \mathrm{AlC}_{0.5} \mathrm{~N}_{0.5}$. Metall Mater Trans A 2000;31:1857-1865.

[4] Radovic M, Ganguly A, Barsoum MW. Elastic properties and phonon conductivities of $\mathrm{Ti}_{3} \mathrm{Al}\left(\mathrm{C}_{0.5} \mathrm{~N}_{0.5}\right)_{2}$ and $\mathrm{Ti}_{2} \mathrm{Al}\left(\mathrm{C}_{0.5} \mathrm{~N}_{0.5}\right)$ solid solutions. J Mater Res 2008;23:1517-1521.

[5] Du YL, Sun ZM, Hashimoto H, Barsoum MW. Theoretical investigations on the elastic and thermodynamic properties of $\mathrm{Ti}_{2} \mathrm{AlC}_{0.5} \mathrm{~N}_{0.5}$ solid solution. Phys Lett $\mathrm{A}$ 2009;374:78-82.

[6] Wilhelmsson O, Palmquist JP, Lewin E, Emmerlich J, Eklund P, Persson POA, Högberg H, Li S, Ahuja R, Eriksson O, Hultman L, Jansson U. Deposition and characterization of ternary thin films within the Ti-Al-C system by DC magnetron sputtering. $\mathrm{J}$ Cryst Growth 2006;291:290-300.

[7] Persson POÅ, Rosén J, McKenzie DR, Bilek MMM, Höglund C. A solid phase reaction between $\mathrm{TiC}_{\mathrm{x}}$ thin films and $\mathrm{Al}_{2} \mathrm{O}_{3}$ substrates. J Appl Phys 2008;103:066102.

[8] Persson POA, Rosén J, McKenzie DR, Bilek MMM. Formation of the MAX-phase oxycarbide $\mathrm{Ti}_{2} \mathrm{AlC}_{1-\mathrm{x}} \mathrm{O}_{\mathrm{x}}$ studied via electron energy-loss spectroscopy and firstprinciples calculations. Phys Rev B 2009;80:092102.

[9] Persson POA, Höglund C, Birch J, Hultman $\mathrm{L}$. $\mathrm{Ti}_{2} \mathrm{Al}(\mathrm{O}, \mathrm{N})$ formation by solid-state reaction between substoichiometric TiN thin films and $\mathrm{Al}_{2} \mathrm{O}_{3}(0001)$ substrates. Thin Solid Films 2011;519:2421-2425

[10] Dahlqvist M, Alling B, Abrikosov IA,Rosén J. Stability trends of MAX phases from first principles. Phys Rev B 2010;81:024111.

[11] Pierson HO. Handbook of Refractory carbides and nitrides (Westwood, N): Noves Publications (1996). 
[12] Williams WS. Electrical properties of hard metals. Int J Refract Met Hard Mat 1999;17:21-26.

[13] Williams WS. The thermal conductivity of metallic ceramics. Journal Of the Minerals 1998;50:62-66.

[14] Dolique V, Jaouen M, Cabioc'h T, Pailloux F, Guérin Ph, Pélosin V. Formation of $(\mathrm{Ti}, \mathrm{Al}) \mathrm{N} / \mathrm{Ti}_{2} \mathrm{AlN}$ multilayers after annealing of $\mathrm{TiN} / \mathrm{TiAl}(\mathrm{N})$ multilayers deposited by ion beam sputtering. J Appl Phys 2008;103:083527.

[15] Rawn CJ, Barsoum MW, El-Raghy T, Procopio A, Hoffmann CM, Hubbard CR. Structure of $\mathrm{Ti}_{4} \mathrm{AlN}_{3}$ - A Layered $\mathrm{M}_{n+1} \mathrm{AX}$ Nitride. Mater Res Bull 2000;35:1785-96.

[16] Tzenov N, Barsoum MW. Synthesis and Characterization of $\mathrm{Ti}_{3} \mathrm{AlC}_{1.8}$. J Am Ceram Soc 2000;83:825-832.

[17] Etzkorn J, Ade M, Hillebrecht H. $\mathrm{V}_{2} \mathrm{AlC}, \mathrm{V}_{4} \mathrm{AlC}_{3-\mathrm{x}}(\mathrm{x} \approx 0.31)$ and $\mathrm{V}_{12} \mathrm{Al}_{3} \mathrm{C}_{8}-$ Synthesis, crystal growth, structure, and superstructure. Inorg Chem 2007;46:7646-7653.

[18] Music D, Ahjua R, Schneider JM. Theoretical study of nitrogen vacancies in $\mathrm{Ti}_{4} \mathrm{AlN}_{3}$. Appl Phys Lett 2005;86:031911.

[19] Dahlqvist M, Alling B, Rosén J. Stability trends of MAX phases from first principles. Phys Rev B 2010;81:220102.

[20] Du YL, Sun ZM, Hashimoto H, Tian WB. First-Principles Study of Carbon Vacancy in $\mathrm{Ta}_{4} \mathrm{AlC}_{3}$. Mater Trans 2008;49:1934-36.

[21] Eklund P, Palmquist JP, Höwing J, Trinh DH, El-Raghy T, Högberg H, Hultman L. $\mathrm{Ta}_{4} \mathrm{AlC}_{3}$ : Phase determination, polymorphism and deformation. Acta Mater 2007;55:4723-29.

[22] Etzkorn J, Ade M, Hillebrecht $\mathrm{H}$. $\mathrm{Ta}_{3} \mathrm{AlC}_{2}$ and $\mathrm{Ta}_{4} \mathrm{AlC}_{3}$ - Single crystal investigations of two new ternary carbides of tantalum synthesized by the molten metal technique. Inorg Chem 2007;46:1410-1418.

[23] Pietzka MA, Schuster JC. Phase equilibria in the quaternary system Ti-A1-C-N. J Amer Ceram Soc 1996;79:2321-30.

[24] L. Lutterotti, Materials Analysis Using Diffraction (MAUD) software, http://www.ing.unitn.it/ maud/

[25] Wokulska K. Thermal expansion of whiskers of Ti(C,N) solid solution. J Alloys Comp 1998;264:223-227.

[26] Manoun B, Zhang FX, Saxena SK, El-Raghy T, Barsoum MW. X-Ray pressure study of $\mathrm{Ti}_{2} \mathrm{AlN}$ and $\mathrm{Ti}_{2} \mathrm{AlC}$. J Phys Chem Sol 2006; 67:2091-2094

[27] Hug G, Jaouen M, Barsoum MW. X-ray absorption spectroscopy, EELS, and fullpotential augmented plane wave study of the electronic structure of $\mathrm{Ti}_{2} \mathrm{AlC}, \mathrm{Ti}_{2} \mathrm{AlN}$, $\mathrm{Nb}_{2} \mathrm{AlC}$, and $\left(\mathrm{Ti}_{0.5} \mathrm{Nb}_{0.5}\right)_{2} \mathrm{AlC}$. Phys Rev B 2005; 71:024105

[28] Schuster J, Nowotny H, Vaccaro C. The ternary systems: Cr-Al-C, V-Al-C, and TiAl-C and the behavior of H-Phases ( $\left.\mathrm{M}_{2} \mathrm{AlC}\right)$. J Solid State Chem. 1980; 32:213-219

[29] Pietzka MA, Schuster JC. Summary of constitutional data on the aluminiumcarbon-titanium system. J Phase Equil. 1994; 15:392-400

[30] Gamamik MY, Barsoum MW, El-Raghy T. Improved X-ray powder diffraction data for $\mathrm{Ti}_{2} \mathrm{AlN}$. Powder Diffraction 2000; 15:241-242.

[31] Nowotny H. Struktuchemie Einger verbindungen der ubergangsmetalle mit den elementen C, Si, Ge,Sn. Prog Solid State Chem 1970;2:27-70.

[32] Arróyave R, Radovic M. Ab initio investigation of $\mathrm{Ti}_{2} \mathrm{Al}(\mathrm{C}, \mathrm{N})$ solid solutions. Phys Rev B 2011; 84:134112. 
[33] Popa C. The $(h \mathrm{kl})$ dependence of diffraction-line broadening caused by strain and size for all Laue groups in Rietveld refinement. J Appl Cryst 1998;31:176-180.

[34] Lin ZJ, Zhuo MJ, Zhou YC, Li. MS, Wang JY. Microstructural characterization of layered ternary $\mathrm{Ti}_{2} \mathrm{AlC}$. Acta Mat 2006;54:1009-1015. 


\begin{tabular}{|c|c|c|c|c|c|c|}
\hline $\begin{array}{c}\mathrm{X} \\
\text { (C at. conc.) } \\
\end{array}$ & 0 & 0.25 & 0.5 & 0.75 & 1 & \\
\hline \multirow[b]{2}{*}{$\mathrm{a}(\mathrm{nm})$} & $0.29891(2)$ & $0.30071(1)$ & $0.30250(5)$ & $0.30462(4)$ & $0.30625(5)$ & This work \\
\hline & $\begin{array}{l}0.29888 \pm \\
0.00018\end{array}$ & & $\begin{array}{c}0.30220 \pm \\
0.0001\end{array}$ & & $\begin{array}{c}0.30515 \pm \\
0.00129\end{array}$ & $\begin{array}{c}\text { Experi- } \\
\text { mental val- } \\
\text { ues from } \\
\text { literature }\end{array}$ \\
\hline \multirow[b]{2}{*}{$\mathrm{c}(\mathrm{nm})$} & $1.3615(1)$ & $1.3605(4)$ & $1.3608(4)$ & $1.3614(5)$ & $1.3668(1)$ & This work \\
\hline & $\begin{array}{c}1.36123 \pm \\
0.00072\end{array}$ & & 1.36100 & & $\begin{array}{c}1.36423 \pm \\
0.00495\end{array}$ & $\begin{array}{c}\text { Experi- } \\
\text { mental val- } \\
\text { ues from } \\
\text { literature }\end{array}$ \\
\hline
\end{tabular}

Table 1

Lattice parameters of $\mathrm{Ti}_{2} \mathrm{AlC}_{\mathrm{x}} \mathrm{N}_{(1-\mathrm{x})}$ for various carbon contents deduced from Rietveld refinement of XRD spectra (this work). Lattice parameters from the literature are also given. The experimental values from the literature correspond to average values (5 values from $[3,27,28,32,33]$ for $\mathrm{x}=0,2$ values from ref $[3,4]$ for $\mathrm{x}=0.5$ and 22 values from ref $[3,27,28,29,31,33]$ for $x=1$. The associated uncertainty is the standard deviation for $\mathrm{x}=0$ and $\mathrm{x}=1$ and the difference between maximum and minimum values for $\mathrm{x}=0.5$.

\begin{tabular}{cc|cc}
\hline $\mathrm{x}$ & $\mathrm{x}_{\mathrm{t}}$ & $\mathrm{y}$ & $\mathrm{y}_{\mathrm{t}}$ \\
\hline 0 & 0 & 1 & 1 \\
0 & 0 & 0.85 & $0.90 \pm 0.02$ \\
0 & 0 & 0.7 & $0.85 \pm 0.02$ \\
\hline 0.25 & $0.24 \pm 0.01$ & 1 & $1.00 \pm 0.02$ \\
0.25 & $0.25 \pm 0.02$ & 0.9 & $0.92 \pm 0.04$ \\
0.25 & $0.25 \pm 0.01$ & 0.8 & $0.86 \pm 0.02$ \\
\hline 0.5 & $0.49 \pm 0.02$ & 1 & $1.00 \pm 0.05$ \\
0.5 & $0.50 \pm 0.02$ & 0.85 & $0.88 \pm 0.04$ \\
0.5 & $0.51 \pm 0.04$ & 0.7 & $0.80 \pm 0.03$ \\
\hline 0.75 & $0.74 \pm 0.01$ & 1 & $0.97 \pm 0.03$ \\
0.75 & $0.74 \pm 0.02$ & 0.9 & $0.96 \pm 0.04$ \\
0.75 & $0.75 \pm 0.02$ & 0.8 & $0.88 \pm 0.04$ \\
\hline 1 & 1.00 & 1 & $0.89 \pm 0.04$ \\
1 & 1.00 & 0.9 & $0.95 \pm 0.02$ \\
1 & 1.00 & 0.8 & $0.96 \pm 0.02$ \\
1 & 1.00 & 0.7 & $0.98 \pm 0.03$ \\
\hline
\end{tabular}

Table 2

Values of $\mathrm{x}$ (Carbon content) and $\mathrm{y}$ (total stoichiometry in $\mathrm{C}$ and/or $\mathrm{N}$ ) of the reactants compared to the values $x_{t}$ and $y_{t}$ of the product $\left.\operatorname{Ti}_{2} \mathrm{Al}\left(\mathrm{C}_{\mathrm{x}_{t}} \mathrm{~N}_{(1-\mathrm{xt}}\right)\right)_{\mathrm{y}_{t}}$ deduced from Rietveld refinements of the XRD diffractograms. 


\begin{tabular}{cc|cc|cc}
\hline \multirow{2}{*}{ Reactants } & \multicolumn{4}{c}{ Products } & \multicolumn{2}{c}{ EELS } \\
& & \multicolumn{2}{|c|}{ Rietveld refinement of } & \multicolumn{2}{c}{} \\
\hline $\mathrm{x}$ & $\mathrm{y}$ & $\mathrm{x}_{\mathrm{t}}$ & $\mathrm{y}_{\mathrm{t}}$ & $\mathrm{x}_{\mathrm{t}}$ & $\mathrm{y}_{\mathrm{t}}$ \\
\hline 0.5 & 1 & $0.49 \pm 0.02$ & $1 \pm 0.05$ & $0.5 \pm 0.05$ & $1 \pm 0.1$ \\
0.5 & 0.7 & $0.51 \pm 0.04$ & $0.8 \pm 0.03$ & $0.5 \pm 0.05$ & $0,76 \pm 0.08$ \\
\hline
\end{tabular}

Table 3

Comparison between $\mathrm{x}_{\mathrm{t}}$ and $\mathrm{y}_{\mathrm{t}}$ values deduced from XRD Rietveld and EELS analysis. 


\section{Figure Captions}

Figure 1: Typical SEM micrographies (secondary electrons) of a polished section of $\left.\mathrm{Ti}_{2} \mathrm{AlC}_{\mathrm{x}} \mathrm{N}_{(1-\mathrm{x}}\right)$ samples. Large scale view (a) and higher magnification micrography from an area between denser aggregates (b).

Figure 2: XRD diffractograms and Rietveld refinements of $\mathrm{Ti}_{2} \mathrm{AlC}_{\mathrm{x}} \mathrm{N}_{(1-\mathrm{x})}$ compounds. Residual is shown below every diffractogram. (a) Typical XRD diffractogram obtained for the case $x=0.5$ in the $10-80^{\circ} 2 \theta$ range. (b) Evolution of the XRD diffractograms for various $x$ values in the $50-80^{\circ} 2 \theta$ range (Main diffraction peaks come from $\mathrm{Ti}_{2} \mathrm{AlC}_{\mathrm{x}} \mathrm{N}_{(1-}$ x). Only clearly visible diffraction peaks from secondary phases are indexed).

Figure 3: Evolution of the $a$ and c lattice parameters ((a) and (b) respectively) as a function of carbon content of the $\mathrm{Ti}_{2} \mathrm{AlC}_{\mathrm{x}} \mathrm{N}_{(1-\mathrm{x})}$ compound. Values from this work are compared with that reported in the literature (average values from several experimental studies), error bars for literature values corresponding to the standard deviation (see Table 1 for further details). In (a), linear regressions are plotted (dashed lines) and the distance $d$ between $\mathrm{Ti}$ atoms in $\mathrm{TiC}_{\mathrm{x}} \mathrm{N}_{(1-\mathrm{x})}$ compounds[25] is given for comparison.

Figure 4: Microstrain values deduced from Rietveld refinements of the XRD spectra for selected well observable diffractions planes.

Figure 5: XRD diffractograms and corresponding Rietveld refinements obtained for $\mathrm{x}=0.25$ for increasing from bottom to top $\mathrm{C}$ and $\mathrm{N}$ content $\mathrm{y}$ in $\mathrm{Ti}_{2} \mathrm{Al}\left(\mathrm{C}_{\mathrm{x}} \mathrm{N}_{(1-\mathrm{x})}\right)_{\mathrm{y}}$. Residual is plotted below each diffractogram.

Figure 6: Weight fractions of the different phases deduced from Rietveld refinements of the X-Ray diffractograms for the different values of $\mathrm{x}$ and $\mathrm{y}$.

Figure 5: XRD diffractograms and corresponding Rietveld refinements obtained for $\mathrm{x}=0.25$ for increasing from bottom to top $\mathrm{C}$ and $\mathrm{N}$ content $\mathrm{y}$ in $\operatorname{Ti}_{2} \mathrm{Al}\left(\mathrm{C}_{\mathrm{x}} \mathrm{N}_{(1-\mathrm{x})}\right)_{\mathrm{y}}$. Residual is plotted below each diffractogram.

Figure 7: Evolution of the $a$ (a), c (b) lattice parameters and (c) unit cell volume of the $\left.\mathrm{Ti}_{2} \mathrm{Al}\left(\mathrm{C}_{\mathrm{x}_{\mathrm{t}}} \mathrm{N}_{(1-\mathrm{xt}}\right)\right)_{\mathrm{y}_{\mathrm{t}}}$ compounds with respect to $\mathrm{x}_{\mathrm{t}}$ and $\mathrm{y}_{\mathrm{t}}$. In (c), values having a star or a cross at their right come from [23] or correspond to average values from the literature (see table 1) respectively. Only error bars for $y_{t}$ are indicated (corresponding to values given in table 2), error bars for lattice parameters being too small to be clearly observable (typically $5 \times 10^{-5} \mathrm{~nm}, 5 \times 10^{-4} \mathrm{~nm}$ and $7 \times 10^{-4} \mathrm{~nm}^{3}$ for a, c lattice parameters and unit cell volume respectively in the case of this study) 

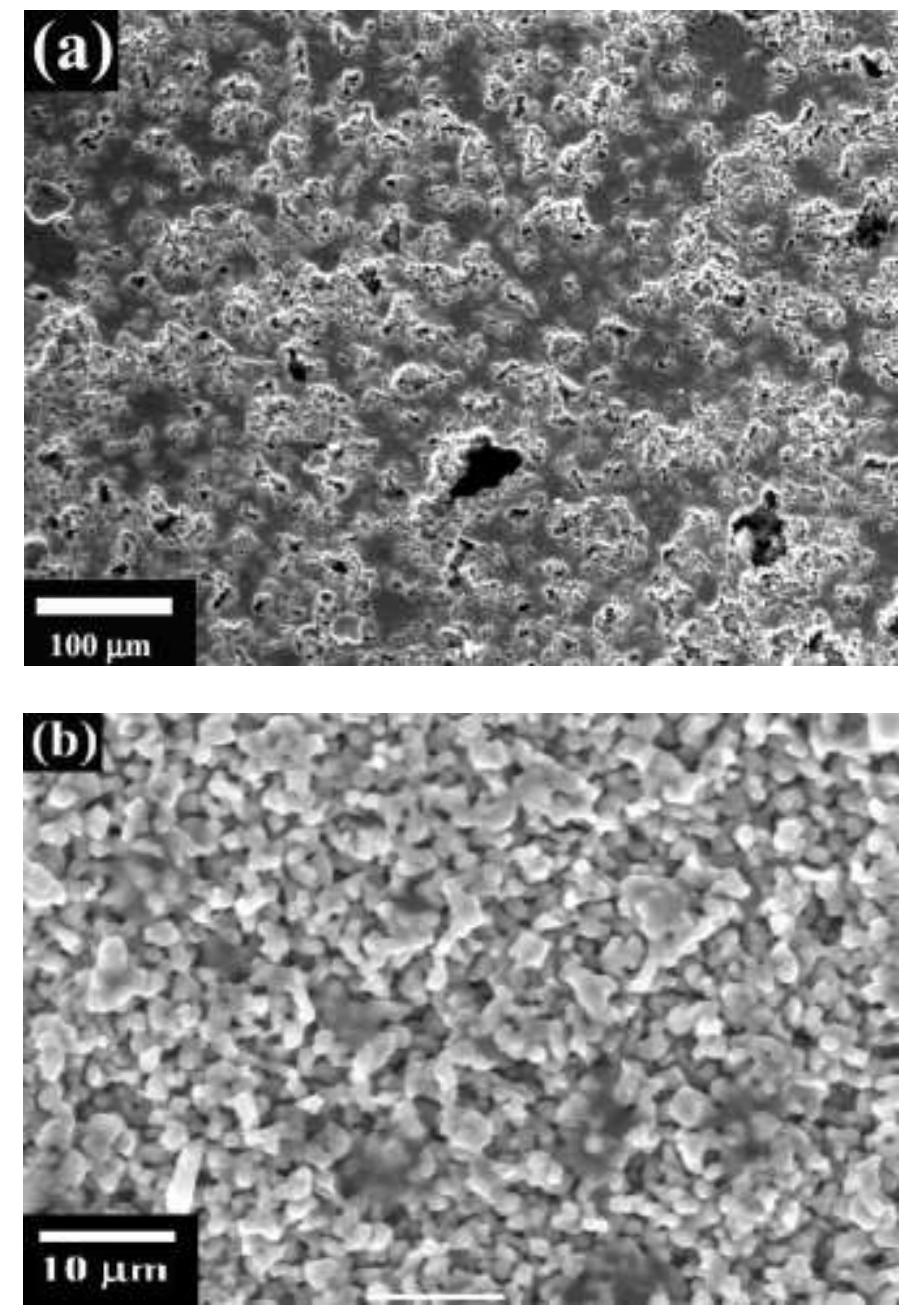

Figure 1: Typical SEM micrographies (secondary electrons) of a polished section of $\mathrm{Ti}_{2} \mathrm{AlC}_{\mathrm{x}} \mathrm{N}_{(1-\mathrm{x}}$ ) samples. Large scale view (a) and higher magnification micrography from an area between denser aggregates (b). 

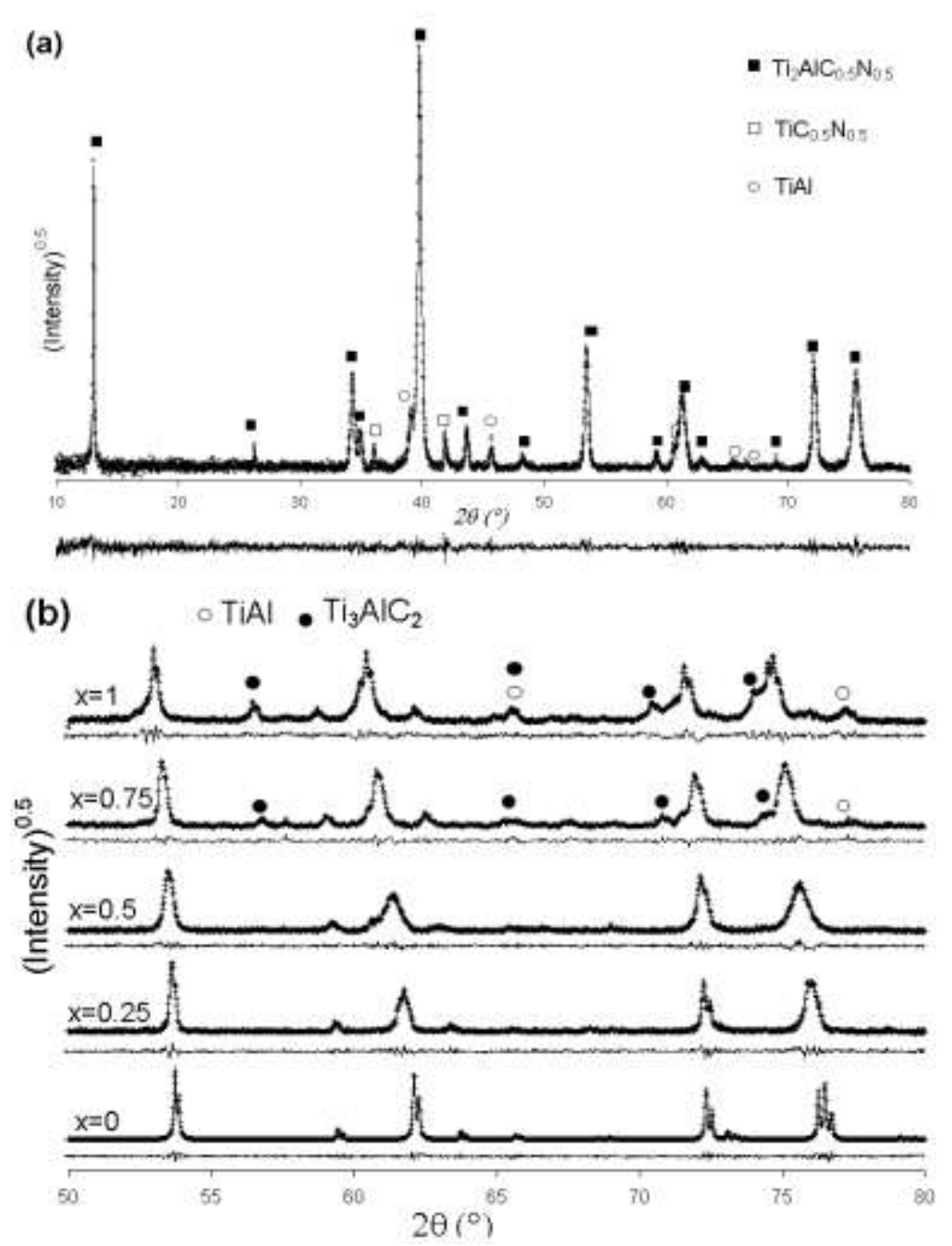

Figure 2: XRD diffractograms and Rietveld refinements of $\mathrm{Ti}_{2} \mathrm{AlC}_{\mathrm{X}} \mathrm{N}_{(1-\mathrm{x})}$ compounds. Residual is shown below every diffractogram. (a) Typical XRD diffractogram obtained for the case $\mathrm{x}=0.5$ in the $10-80^{\circ} 2 \theta$ range. (b) Evolution of the XRD diffractograms for various $x$ values in the $50-80^{\circ} 2 \theta$ range (Main diffraction peaks come from $\operatorname{Ti}_{2} \mathrm{AlC}_{\mathrm{x}} \mathrm{N}_{(1-}$ x). Only clearly visible diffraction peaks from secondary phases are indexed). 

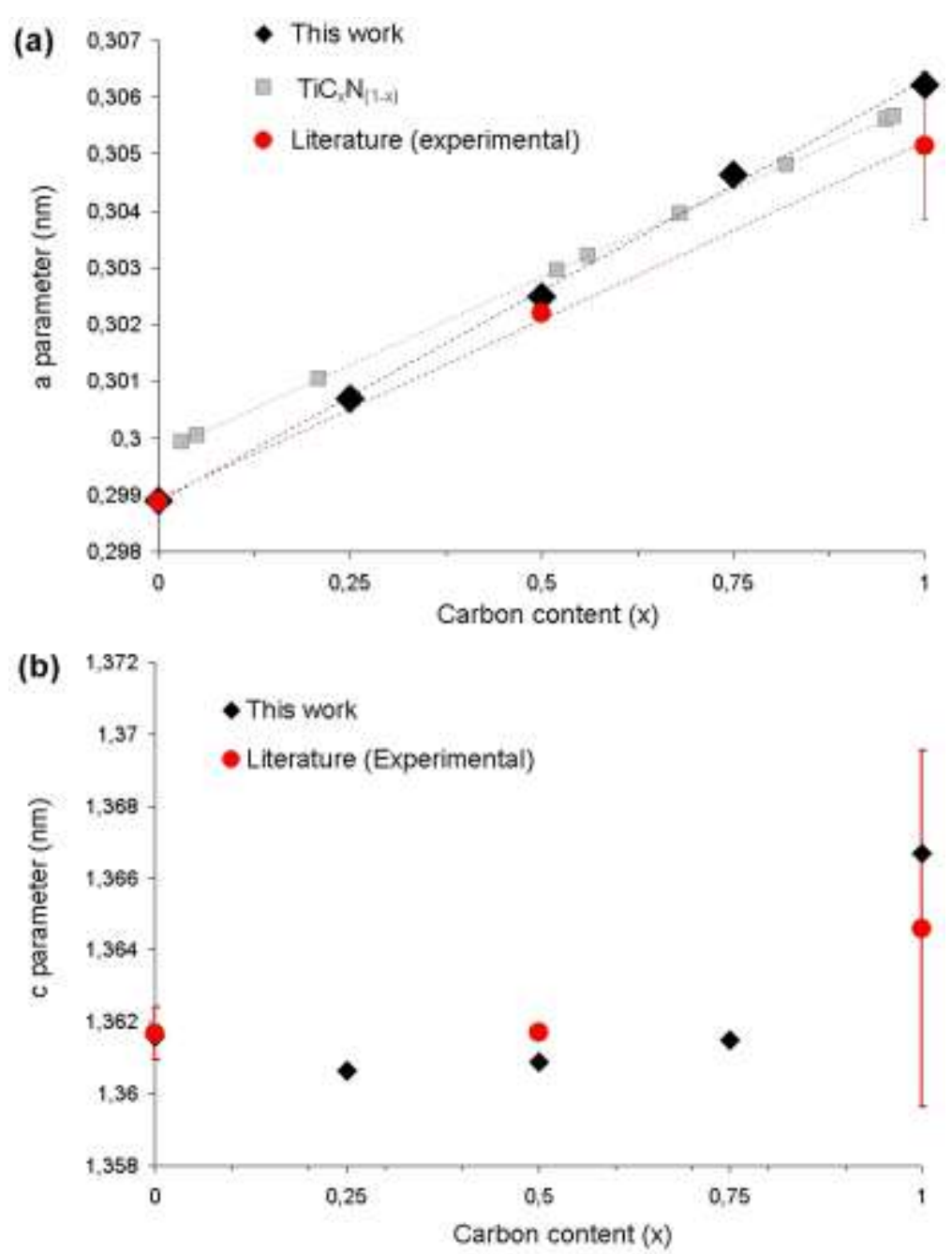

Figure 3: Evolution of the $a$ and c lattice parameters ((a) and (b) respectively) as a function of carbon content of the $\mathrm{Ti}_{2} \mathrm{AlC}_{\mathrm{x}} \mathrm{N}_{(1-\mathrm{x})}$ compound. Values from this work are compared with that reported in the literature (average values from several experimental studies), error bars for literature values corresponding to the standard deviation (see Table 1 for further details). In (a), linear regressions are plotted (dashed lines) and the distance $d$ between $\mathrm{Ti}$ atoms in $\mathrm{TiC}_{\mathrm{x}} \mathrm{N}_{(1-\mathrm{x})}$ compounds[25] is given for comparison. 


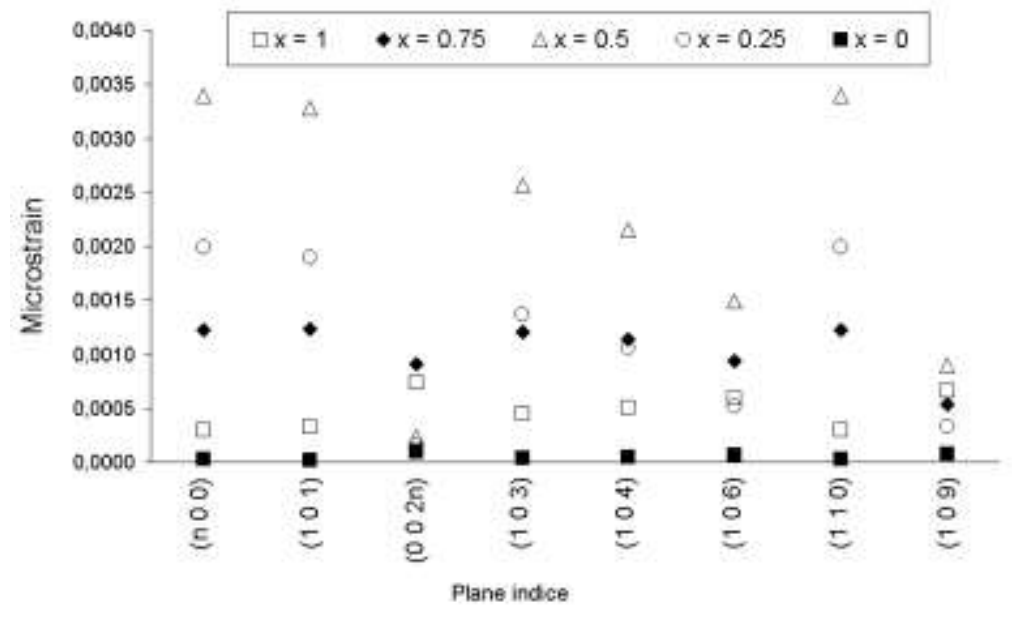

Figure 4: Microstrain values deduced from Rietveld refinements of the XRD spectra for selected well observable diffractions planes. 


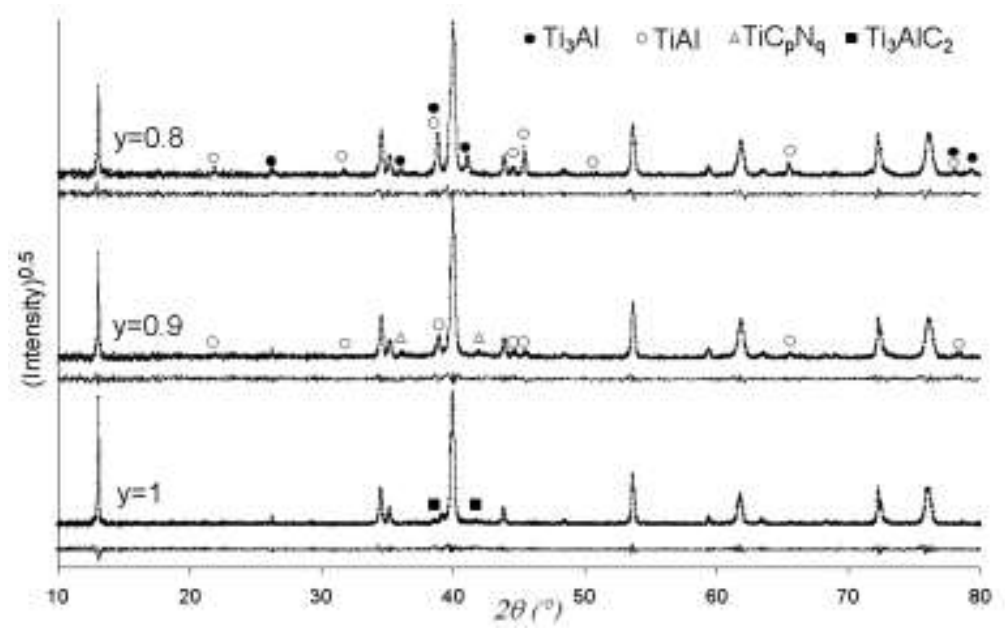

Figure 5: XRD diffractograms and corresponding Rietveld refinements obtained for $\mathrm{x}=0.25$ for increasing from bottom to top $\mathrm{C}$ and $\mathrm{N}$ content $\mathrm{y}$ in $\mathrm{Ti}_{2} \mathrm{Al}\left(\mathrm{C}_{\mathrm{x}} \mathrm{N}_{(1-\mathrm{x})}\right)_{\mathrm{y}}$. Residual is plotted below each diffractogram. 


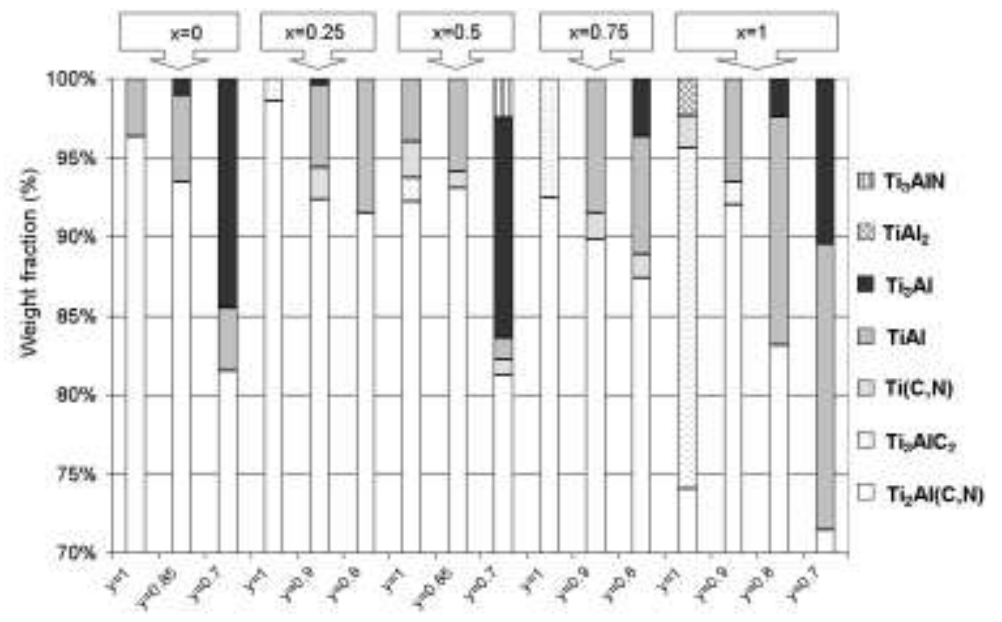

Figure 6: Weight fractions of the different phases deduced from Rietveld refinements of the X-Ray diffractograms for the different values of $\mathrm{x}$ and $\mathrm{y}$. 

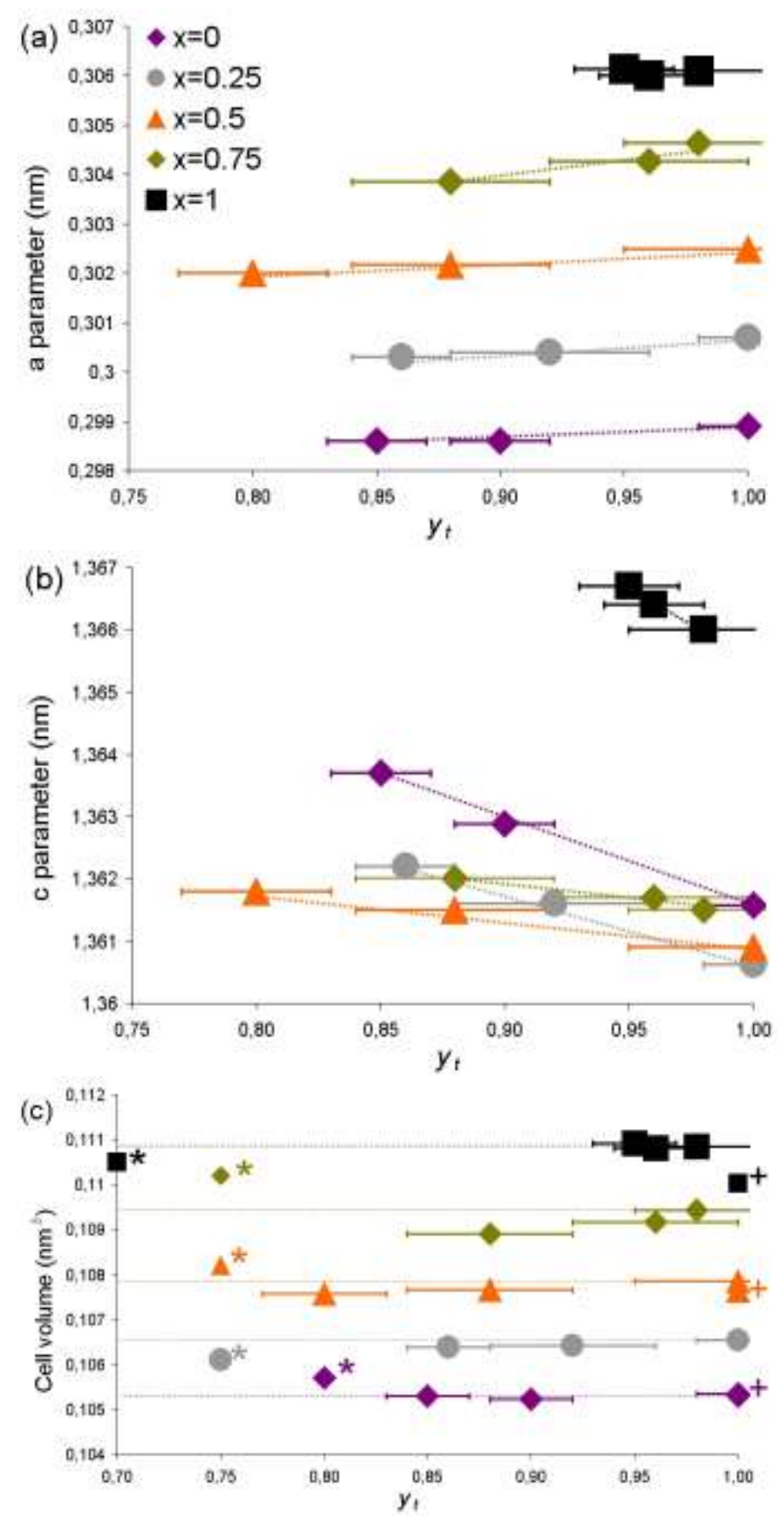

Figure 7: Evolution of the $a$ (a), c (b) lattice parameters and (c) unit cell volume of the $\left.\operatorname{Ti}_{2} \operatorname{Al}\left(\mathrm{C}_{\mathrm{x}_{\mathrm{t}}} \mathrm{N}_{(1-\mathrm{xt}}\right)\right)_{\mathrm{y}_{\mathrm{t}}}$ compounds with respect to $\mathrm{x}_{\mathrm{t}}$ and $\mathrm{y}_{\mathrm{t}}$. In (c), values having a star or a cross at their right come from [23] or correspond to average values from the literature (see table 1) respectively. Only error bars for $\mathrm{y}_{\mathrm{t}}$ are indicated (corresponding to values given in table 2), error bars for lattice parameters being too small to be clearly observable (typically $5 \times 10^{-5} \mathrm{~nm}, 5 \times 10^{-4} \mathrm{~nm}$ and $7 \times 10^{-4} \mathrm{~nm}^{3}$ for a, c lattice parameters and unit cell volume respectively in the case of this study) 